\title{
Penerapan Data Mining Klasifikasi Tingkat Pemahaman Siswa Pada Pelajaran Matematika
}

\author{
Tri Novika $^{1 \text {,* }}$, Poningsih ${ }^{2}$, Harly Okprana ${ }^{1}$, Agus Perdana Windarto ${ }^{1}$, Hasudungan Siahaan ${ }^{1}$ \\ ${ }^{1}$ Program Studi Sistem Informasi, STIKOM Tunas Bangsa, Pematangsiantar, Indonesia \\ ${ }^{2}$ Program Studi Manajemen Informatika, AMIK Tunas Bangsa, Pematangsiantar, Indonesia \\ Email: 1,"trinovika.hr@gmail.com, ${ }^{2}$ poningsih@ amiktunasbangsa.ac.id, ${ }^{3}$ harly@ amiktunasbangsa.ac.id, \\ ${ }^{4}$ agus.perdana@amiktunasbangsa.ac.id, ${ }^{5}$ hasudungansiahan@gmail.com \\ Email Penulis Korespondensi: trinovika.hr@gmail.com
}

\begin{abstract}
Abstrak-Tujuan dari penelitian untuk mengklasifikasi konsep pemahaman siswa pada pelajaran Matematika. Dalam proses belajar mengajar pemahaman siswa terhadap materi pembelajaran sangatlah penting. Tercapainya pemahaman peserta didik merupakan fungsi dari adanya seorang pendidik. Banyak rumus dan konsep yang harus dipahami membuat siswa kesulitan dalam menyelesaikan persoalan matematika. Sumber data diperoleh dari hasil kuesioner pemahaman matematika siswa kelas delapan di SMP Swasta Tamansiswa Tapian Dolok. Metode klasifikasi yang digunakan adalah Algoritma C4.5 dan dibantu dengan software RapidMiner. Atribut yang digunakan yaitu minat siswa, cara belajar siswa, motivasi siswa, cara mengajar guru, media pembelajaran, dan sarana prasarana. Hasil perhitungan nilai entropy dan gain atribut diperoleh 15 rule keputusan pemahaman matematika dengan 9 rules berstatus paham dan 6 rules berstatus tidak paham. Pemodelan klasifikasi dengan Algoritma C4.5 pada RapidMiner diperoleh akurasi sebesar 96.00\%. Klasifikasi dengan Algoritma C4.5 dapat diterapkan dan memberikan informasi baru tentang klasifikasi konsep pemahaman siswa pada pelajaran matematika.
\end{abstract}

Kata Kunci: Data Mining; Klasifikasi; Algoritma C4.5; Pemahaman Siswa; Matematika

Abstract-The purpose of the research is to classify the concept of understanding students in Mathematics lessons. In the learning process teaching students understanding learning materials is very important. The attainment of student understanding is a function of the being of an educator. Many formulas and concepts to understand make it difficult for students to solve math problems. The data source was obtained from the results of a math comprehension questionnaire of eighth graders at Tamansiswa Tapian Dolok Private Junior High School. The classification method used is the C4.5 Algorithm and assisted with RapidMiner software. Attributes used are student interests, how students learn, student motivation, how to teach teachers, learning media, and infrastructure facilities. The results of the calculation of entropy values and attribute gains obtained 15 rules of mathematical comprehension decisions with 9 rules of understanding status and 6 rules of inconsistency status. Classification modeling with C4.5 Algorithm on RapidMiner obtained 96.00\% accuracy Classification with C4.5 Algorithm can be applied and provide new information about the classification of student comprehension concepts in math lessons.

Keywords: Data Mining; Classification; Algorithm C4.5; Student Comprehension; Mathematics

\section{PENDAHULUAN}

Sekolah Menengah Pertama merupakan sarana penyelenggara pendidikan formal bagi siswa. Dalam proses belajar mengajar pemahaman siswa terhadap materi pembelajaran sangatlah penting. Tercapainya pemahaman peserta didik atau siswa merupakan fungsi dari adanya seorang pendidik. Dari pemahaman tersebut peserta didik diharapkan bisa menjelaskan sebagian atau seluruh materi pelajaran yang telah disampaikan oleh guru. Matematika seringkali dianggap sebagai materi pelajaran yang sulit oleh siswa. Seperti halnya siswa kelas VIII (delapan) di SMP Swasta Tamansiswa Tapian Dolok, mereka sulit memahami mata pelajaran matematika khususnya untuk materi bangun ruang sisi datar. Banyaknya konsep-konsep yang harus dipahami membuat siswa kesulitan dalam menyelesaikan persoalan matematika. Selain itu banyak siswa menganggap bahwa matematika hanya bisa dipelajari oleh siswa yang pintar. Kebanyakan siswa hanya memahami soal yang dikerjakan sebagai contoh dan penjelasan yang diberikan guru. Namun ketika bentuk soal berbeda dari contoh yang diberikan guru, mereka sulit untuk mengembangkan kognitif dalam menyelesaikan soal pada materi. Hal tersebut karena dalam proses pembelajaran matematika, pemahaman konsep merupakan landasan yang sangat penting untuk berpikir dalam menyelesaikan masalah matematika maupun permasalahan sehari-hari. Siswa mudah paham atau sulit memahami pelajaran matematikan dikarenakan beberapa faktor yang mempengaruhi siswa untuk paham dengan pelajaran matematika. Beberapa faktor yang mempengaruhi pemahaman konsep matematika yaitu faktor internal yang berasal dari siswa itu sendiri seperti minat siswa, cara belajar siswa, motivasi siswa dalam belajar dan pengetahuan siswa dan faktor eksternal yaitu faktor yang berasal dari luar siswa seperti sarana dan prasarana yang mendukung belajar siswa, media yang digunakan dan penyampaian guru dalam proses pembelajaran [1]. Dari permasalahan tersebut, maka diperlukan suatu metode yang dapat mengklasifikasikan konsep pemahaman siswa agar diperoleh suatu pola hubungan dari faktor yang mempengaruhi pemahaman siswa sehingga dapat diambil sebuah keputusan atau tindakan yang perlu dilakukan untuk membantu dan meningkatkan pemahaman siswa pada pelajaran matematika.

Data Mining merupakan proses penggalian data didalam database dengan menggunakan teknik tertentu untuk memperoleh pengetahuan atau informasi yang baru[2]-[6]. Teknik-teknik yang digunakan untuk pengekstrakan pengetahuan dalam data mining diantaranya estimasi, clustering, asosiasi, prediksi dan 
klasifikasi[7], [8]. Klasifikasi merupakan salah satu teknik data mining yang bertujuan untuk menggambarkan suatu model pengetahuan berdasarkan ciri persamaan atau perbedaan dari suatu kelas data[9]. Dari permasalahan diatas penulis menggunakan teknik data mining klasifikasi dengan Algoritma C4.5 untuk mendapatkan solusi yang lebih efisien pada tingkat pemahaman siswa terhadap mata pelajaran matematika. Algoritma C4.5 merupakan salah satu Algoritma decision tree yang digunakan untuk melakukan klasifikasi atau segmentasi yang bersifat prediktif [10]. Algoritma C4.5 memiliki kelebihan diantaranya menghasilkan model pohon keputusan yang mudah diinterprestasikan, memiliki tingkat akurasi yang tinggi, dapat efisien dalam menangani atribut bertipe diskret dan numerik[11]-[13].

Banyak penelitian yang telah memanfaatkan kelebihan metode klasifikasi dengan algoritma C4.5 untuk menyelesaikan permasalahan. Diantaranya [2] yang memanfaatkan kelebihan dari Algoritma C4.5 pada kasus faktor kesulitan mahasiswa pada bahasa pemrograman. Hasil penelitian menyatakan bahwa faktor minat menjadi node pertama yang berpengaruh mahasiswa paham terhadap bahasa pemrograman. Selanjutnya penelitian [5] pada kasus tingkat pemahaman mahasiswa terhadap matakuliah dengan tingkat akurasi dari model klasifikasi Algoritma C4.5 sebesar 87,10\%

Dari uraian di atas yang menjadi pertanyaan dalam penelitian adalah bagaimana menerapkan klasifikasi dengan Algoritma C4.5 pada kasus pemahaman pelajaran matematika siswa kelas VIII (delapan) SMP swasta Tamansiswa Tapian Dolok dan menguji model klasifikasi Algoritma C4.5 dengan bantuan software RapidMiner. Sehingga hasil dari penelitian ini akan dihasilkan pohon keputusan yang dapat dijadikan sebagai tolak ukur pada tingkat pemahaman siswa. Diharapkan hasil dari penelitian dapat memberikan kontribusi untuk meningkatkan pemahaman siswa terhadap materi pelajaran khususnya matematika dan meningkatkan kualitas pembelajaran agar tercapainya pendidikan yang unggul dan berprestasi.

\section{METODOLOGI PENELITIAN}

\subsection{Tahapan Metodologi Penelitian}

Pada tahapan penelitian ini menguraikan metodologi dan kerangka kerja penelitian yang digunakan dalam menyelesaikan masalah penelitian. Berikut ini adalah tahapan metodologi penelitian yang ditunjukan pada gambar berikut :

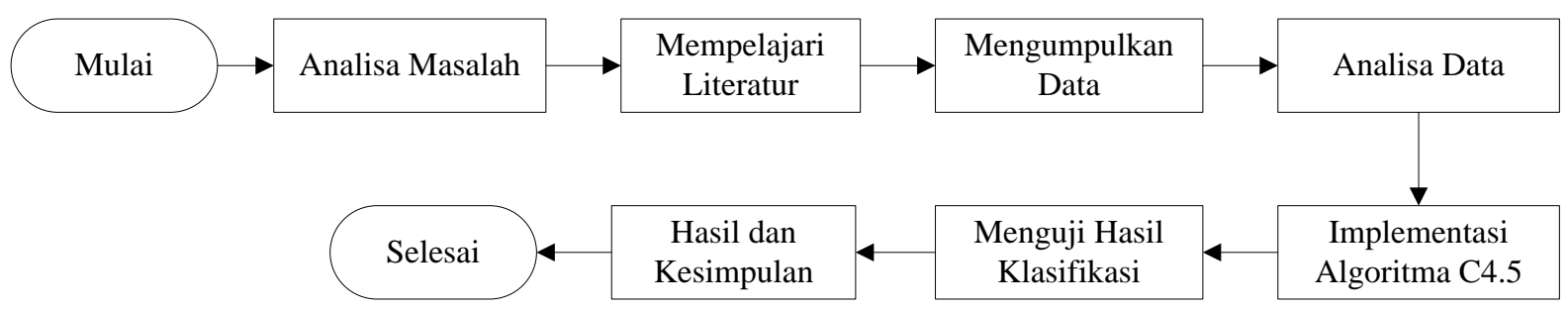

Gambar 1. Metodologi Penelitian

Berdasarkan gambar 1 diatas dapat dijelaskan proses tahapan metodologi penelitian untuk klasifikasi pemahaman siswa pada pelajaran matematika :

1. Analisa Masalah

Penulis menganalisa masalah yang akan menjadi pokok penelitian yaitu kesulitan yang dialami oleh siswa SMP Swasta Tamansiswa dalam memahami pelajaran matematika yang telah diuraikan pada rumusan masalah dipendahuluan.

2. Mempelajari Literatur

Penelitian ini didasari rujukan yang digunakan untuk mendapatkan informasi dan teori yang mendukung penelitian.

3. Mengumpulkan Data

Proses pengumpulan data dilakukan dengan dua cara yaitu: studi kepustakaan dan studi lapangan. Studi kepustakaan dilakukan untuk memahami penerapan data mining seperti mengumpulkan teori-teori yang berhubungan dengan data mining dan studi lapangan dilakukan mendapatkan data penelitian. Data penelitian diperoleh dengan menggunakan kuesioner yang diisi oleh siswa kelas VIII (delapan) SMP Swasta Tamansiswa Tapian Dolok

4. Analisa Data

Data yang telah dikumpulakan selanjutnya dianalisa dengan menyeleksi data yang meliputi pembersihan data (membuang data yang tidak konsisten dan noise) dan integrasi data(penggabungan data dari beberapa sumber) dan melakukan transformasi data dibutuhkan dalam proses penyelesaian masalah.

5. Implementasi Algoritma C4.5

Pada penelitian ini penulis menggunakan teknik data mining klasifikasi dengan Algoritma C4.5 untuk mencari solusi permasalahan penelitian. Pada tahap implementasi Algoritma C4.5 dilakukan proses 
perhintungan nilai entropy dan gain pada setiap atribut dan melakukan proses pengujian dari model yang dihasilkan.

6. Pengujian Hasil Klasifikasi

Proses pengujian hasil klasifikasi Algoritma C4.5 dilakukan dengan bantuan software RapidMiner. Proses pengujian dilakukan untuk mengetahui apakah model yang dihasilakn valid dan sesuai dengan hasil perhitungan yang dilakukan dan melihat tingkat akurasi dari model penyelesaian masalah pemahaman siswa pada pelajaran matematika.

7. Hasil dan Kesimpulan

Hasil implementasi klasifikasi Algoritma C4.5 menghasilkan model pohon keputusan dan aturan rules serta nilai akurasi dari model yang dihasilkan. Kesimpulan yang diperoleh dari klasifikasi tingkat pemahaman siswa pada pelajaran matematika memberikan keputusan yang dapat dijadikan sebagai rekomendasi dalam meningkatkan kualitas pembelajaran dan prestasi siswa dibidang akademik.

\subsection{Analisa Data}

Data yang digunakan adalah hasil kuesioner yang diberikan kepada siswa kelas VIII (delapan) SMP Swasta Tamansiswa Tapian Dolok Tahun Ajaran 2019/2020. Dari hasil kuesioner yang dilakukan penulis mengambil sampel data sebanyak 100 responden. Kemudian melakukan transformasi data kuesioner dalam beberapa dataset berbentuk spreadsheet file Excel. Transformasi data ini diperlukan sebagai input untuk pengujian pada RapidMiner yang dilakukan dalam penelitian ini. Adapun atribut penilaian dalam melakukan klasifikasi terhadap tingkat pemahaman siswa pada pelajaran matematika yaitu Minat Siswa (C1), Cara Belajar Siswa (C2), Motivasi Siswa (C3), Cara Guru Mengajar (C4), Media Pembelajaran (C5), Sarana Prasarana (C6) dan atribut target pemahaman yaitu siswa paham atau tidak paham pada pelajaran matematika. Berikut adalah data penelitian yang ditunjukkan pada tabel 1.

Tabel 1. Data Hasil Rekapitulasi Kuesioner Penelitian

\begin{tabular}{|c|c|c|c|c|c|c|c|}
\hline Responden & $\begin{array}{l}\text { Minat } \\
\text { Siswa }\end{array}$ & $\begin{array}{c}\text { Cara Belajar } \\
\text { Siswa }\end{array}$ & $\begin{array}{c}\text { Motivasi } \\
\text { Siswa }\end{array}$ & $\begin{array}{c}\text { Cara Mengajar } \\
\text { Guru }\end{array}$ & $\begin{array}{c}\text { Media } \\
\text { Pembelajaran } \\
\end{array}$ & $\begin{array}{c}\text { Sarana dan } \\
\text { Prasarana }\end{array}$ & Pemahaman \\
\hline Responden 1 & Baik & Baik & Baik & Sangat Baik & Baik & Baik & Paham \\
\hline Responden 2 & Cukup & Cukup & Cukup & Baik & Kurang & Cukup & Tidak Paham \\
\hline Responden 3 & Cukup & Cukup & Cukup & Baik & Kurang & Cukup & Tidak Paham \\
\hline Responden 4 & Cukup & Cukup & Cukup & Baik & Cukup & Cukup & Tidak Paham \\
\hline Responden 5 & Cukup & Cukup & Cukup & Baik & Baik & Cukup & Tidak Paham \\
\hline Responden 6 & Cukup & Kurang & Cukup & Baik & Cukup & Cukup & Tidak Paham \\
\hline Responden 7 & Baik & Cukup & Cukup & Baik & Cukup & Cukup & Tidak Paham \\
\hline Responden 8 & Kurang & Baik & Cukup & Cukup & Cukup & Baik & Tidak Paham \\
\hline Responden 9 & Cukup & Cukup & Sangat Baik & Baik & Cukup & Cukup & Paham \\
\hline $\mathrm{s} / \mathrm{d}$ & $\ldots$ & $\ldots$ & $\ldots$ & $\ldots$ & $\ldots$ & $\ldots$ & $\ldots$ \\
\hline Responden 98 & Sangat Baik & Sangat Baik & Sangat Baik & Sangat Baik & Sangat Baik & Sangat Baik & Paham \\
\hline Responden 99 & Cukup & Baik & Sangat Baik & Sangat Baik & Baik & Sangat Baik & Paham \\
\hline Responden 100 & Baik & Cukup & Baik & Sangat Baik & Sangat Baik & Baik & Paham \\
\hline
\end{tabular}

\subsection{Data Mining}

Data mining bagian dari Knowledge Discovery in Database (KDD) merupakan serangkaian proses penggalian informasi di dalam database yang meliputi [14]:

a. seleksi data (selection),

b. pemilihan data (preprocessing /cleaning),

c. transformasi (transformation),

d. data mining,

e. interpretasi/evaluasi (interpretation/evaluating).

\subsection{Algoritma C4.5}

Algoritma C4.5 merupakan klasifikasi decision tree yang melakukan partisi rekrusif atas ruang instance untuk mendeskripsikan atribut-atribut dan menggambarkan setiap cabang dan daun dari hasil atribut yang diuji hingga tiap atribut memiliki kelas yang sama[15]-[17]. Berikut ini adalah tahapan dari Algoritma C4.5 yang digambarkan pada flowchart dibawah ini [18]: 
ISSN 2614-5278 (media cetak), ISSN 2548-8368 (media online)

Available Online at https://ejurnal.stmik-budidarma.ac.id/index.php/mib DOI 10.30865/mib.v5i1.2498

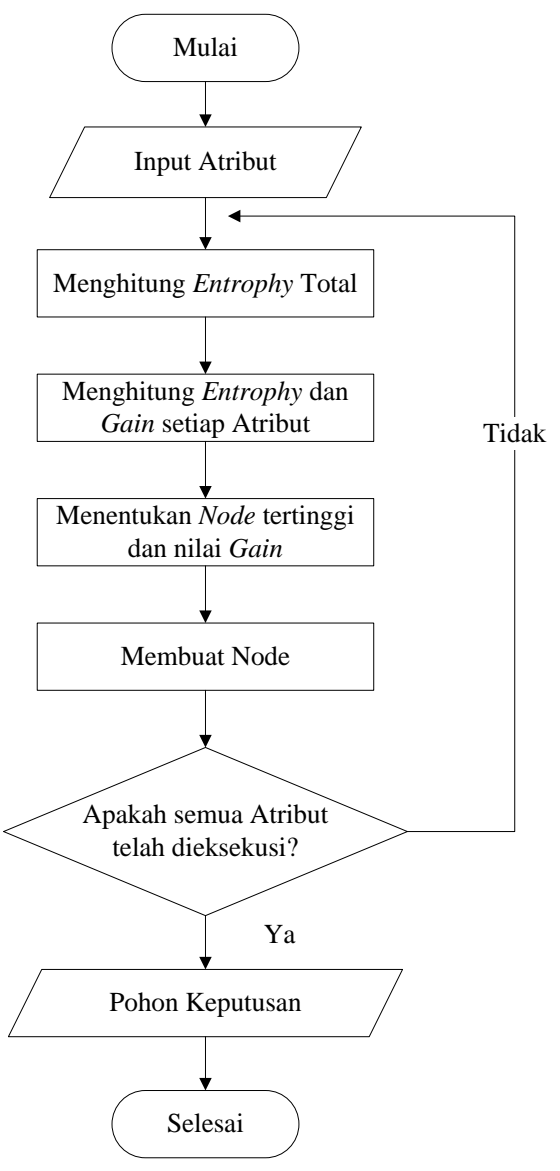

Gambar 2. Flowchart Algoritma C4.5

berikut:

Dari gambar di atas dapat dijelaskan langkah-langkah melakukan klasifikasi Algoritma C4.5 sebagai

a. Input data atribut

b. Memilih atribut sebagai akar

c. Menghitung nilai entropy total, entropy setiap kelas atribut dan gain atribut. Nilai entropy dihitung dengan persamaan (1) dan nilai gain dihitung dengan persamaan (2).

$\operatorname{Entropy}(A)=\sum_{i=1}^{n}-p i * \log _{2} p i$

$\operatorname{Gain}(S, A)=\operatorname{Entropy}(S)-\sum_{i=1}^{n} \frac{|S i|}{|S|} * \operatorname{Entropy}(S i)$

Keterangan :

$\mathrm{S}$ : Himpunan kasus

A : Atribut

$\mathrm{N}$ : Jumlah partisi atribut A

n : Jumlah partisi S

pi : Proporsi dari Si terhadap S

|Si| : jumlah kasus pada partisi ke-1

$|S|$ : Jumlah kasus dalam $S$

d. Membuat node dariatribut yang mempunyai gain tertinggi. Node ini memiliki instance sehingga instance dijadikan sebagai cabang dari node

e. Ulangi proses untuk setiap cabang sampai semua kasus pada semua cabang memiliki kelas yang sama.

f. Model pohon keputusan

\section{HASIL DAN PEMBAHASAN}

Dalam implementasi hasil akhir dari penerapan Algoritma C4.5 pada klasifikasi konsep pemahaman siswa pada pelajaran matematika dibagi ke dalam dua tahap yaitu proses perhitungan menggunakan Algoritma C4.5 dan pengujian model klasifikasi menggunakan software RapidMiner. Data yang digunakan adalah hasil kuesioner yang tertera di tabel 1 sebagai input untuk membuat model aturan menggunakan Algoritma C4.5. Pohon keputusan digunakan untuk membuat model aturan yang akan dipilih dalam pengambilan keputusan. 


\section{JURNAL MEDIA INFORMATIKA BUDIDARMA}

Volume 5, Nomor 1, Januari 2021, Page 9-17

ISSN 2614-5278 (media cetak), ISSN 2548-8368 (media online)

Available Online at https://ejurnal.stmik-budidarma.ac.id/index.php/mib DOI 10.30865/mib.v5i1.2498

\subsection{Penerapan Algoritma C4.5}

Proses perhitungan untuk klasifikasi pemahaman siswa pada pelajaran matematika siswa kelas VIII (delapan) SMP Swasta Tamansiswa Tapian Dolok menggunakan Algoritma C4.5 adalah sebagai berikut :

a. Menghitung jumlah kasus, jumlah kasus untuk respon paham dan jumlah kasus respon tidak paham.

b. Menghitung Entropy dari semua kasus dan kasus yang dibagi berdasarkan kelas atribut minat siswa, cara belajar siswa, motivasi siswa, cara mengajar guru, media pembelajaran dan sarana prasarana. Setelah itu lakukan perhitungan Gain untuk setiap atribut.

Tabel 2. Hasil Perhitungan Node 1

\begin{tabular}{|c|c|c|c|c|c|c|}
\hline Node & & $\begin{array}{c}\text { Jumlah } \\
\text { Kasus } \\
(\mathbf{S})\end{array}$ & $\begin{array}{c}\text { Paham } \\
\text { (S1) }\end{array}$ & $\begin{array}{c}\text { Tidak } \\
\text { Paham } \\
\text { (S2) }\end{array}$ & Entropy & Gain \\
\hline \multirow[t]{31}{*}{1} & TOTAL & 100 & 75 & 25 & 0,811278124 & \\
\hline & Minat Siswa & & & & & 0,22214619 \\
\hline & Sangat Baik & 21 & 21 & 0 & 0 & \\
\hline & Baik & 41 & 36 & 5 & 0,534943699 & \\
\hline & Cukup & 37 & 18 & 19 & 0,99947302 & \\
\hline & Kurang & 1 & 0 & 1 & 0 & \\
\hline & Cara Belajar Siswa & & & & & 0,328351786 \\
\hline & Sangat Baik & 22 & 21 & 1 & 0,266764988 & \\
\hline & Baik & 47 & 44 & 3 & 0,342463772 & \\
\hline & Cukup & 28 & 10 & 18 & 0,940285959 & \\
\hline & Kurang & 3 & 0 & 3 & 0 & \\
\hline & Motivasi Siswa & & & & & 0,392754673 \\
\hline & Sangat Baik & 28 & 28 & 0 & 0 & \\
\hline & Baik & 51 & 44 & 7 & 0,57700425 & \\
\hline & Cukup & 21 & 3 & 18 & 0,591672779 & \\
\hline & Kurang & 0 & 0 & 0 & 0 & \\
\hline & Cara Mengajar Guru & & & & & 0,210776607 \\
\hline & Sangat Baik & 56 & 53 & 3 & 0,301378644 & \\
\hline & Baik & 40 & 21 & 19 & 0,998195879 & \\
\hline & Cukup & 4 & 1 & 3 & 0,811278124 & \\
\hline & Kurang & 0 & 0 & 0 & 0 & \\
\hline & Media Pembelajaran & & & & & 0,313535272 \\
\hline & Sangat Baik & 32 & 32 & 0 & 0 & \\
\hline & Baik & 48 & 38 & 10 & 0,738284866 & \\
\hline & Cukup & 16 & 5 & 11 & 0,896038233 & \\
\hline & Kurang & 4 & 0 & 4 & 0 & \\
\hline & Sarana Dan Prasarana & & & & & 0,378279531 \\
\hline & Sangat Baik & 39 & 38 & 1 & 0,172036949 & \\
\hline & Baik & 40 & 34 & 6 & 0,609840305 & \\
\hline & Cukup & 20 & 3 & 17 & 0,609840305 & \\
\hline & Kurang & 1 & 0 & 1 & 0 & \\
\hline
\end{tabular}

Dari tabel 2 dapat dijelaskan bahwa pada baris total kasus(S) diketahui jumlah kasus adalah 100 dengan jumlah respon paham(S1) adalah 75 dan jumlah respon tidak paham(S2) adalah 25. Perhitungan entropy total dihitung dengan menggunakan persamaan (1) sebagai berikut :

$$
\text { Entropy [Total] } \quad=\left(-\frac{75}{100} x \log _{2}\left(\frac{75}{100}\right)\right)+\left(-\frac{25}{100} x \log _{2}\left(\frac{25}{100}\right)\right)=0,811278124
$$

Selanjutnya dilakukan perhitungan nilai entropy pada subkelas atribut dan Gain setiap atribut dengan mengunakan persamaan (1) dan (2) sebagai berikut :

1. Minat Siswa

$$
\begin{array}{ll}
\text { Entropy [Sangat Baik] } & =0 \\
\text { Entropy [Baik] } & =\left(-\frac{36}{41} \times \log _{2}\left(\frac{36}{41}\right)\right)+\left(-\frac{5}{41} x \log _{2}\left(\frac{5}{41}\right)\right)=0,534943699 \\
\text { Entropy [Cukup] } & =\left(-\frac{18}{37} x \log _{2}\left(\frac{18}{37}\right)\right)+\left(-\frac{19}{37} x \log _{2}\left(\frac{19}{37}\right)\right)=0,99947302 \\
\text { Entropy [Kurang] } & =0 \\
\text { Gain }[\text { Minat siswa] } & =0,811278124-\left(\left(\frac{21}{100} x 0\right)+\left(\frac{41}{100} x 0,534943699\right)+\left(\frac{37}{100} x 0,99947302\right)+\right. \\
& \left.\left(\frac{1}{100} x 0\right)\right)=0,22214619
\end{array}
$$

2. Cara Belajar Siswa 
JURNAL MEDIA INFORMATIKA BUDIDARMA

Volume 5, Nomor 1, Januari 2021, Page 9-17

ISSN 2614-5278 (media cetak), ISSN 2548-8368 (media online)

Available Online at https://ejurnal.stmik-budidarma.ac.id/index.php/mib

DOI 10.30865/mib.v5i1.2498

Entropy [Sangat Baik] $=\left(-\frac{21}{22} \times \log _{2}\left(\frac{21}{22}\right)\right)+\left(-\frac{1}{22} \times \log _{2}\left(\frac{1}{22}\right)\right)=0,266764988$

Entropy [Baik]

$=\left(-\frac{44}{47} \times \log _{2}\left(\frac{44}{47}\right)\right)+\left(-\frac{3}{47} \times \log _{2}\left(\frac{3}{47}\right)\right)=0,342463772$

Entropy [Cukup]

Entropy [Kurang]

$=\left(-\frac{10}{28} \times \log _{2}\left(\frac{10}{28}\right)\right)+\left(-\frac{18}{28} \times \log _{2}\left(\frac{18}{28}\right)\right)=0,940285959$

$=0$

Gain $[$ Cara belajar siswa $]=0,811278124-\left(\left(\frac{22}{100} \times 0,266764988\right)+\left(\frac{47}{100} \times 0,342643722\right)+\right.$ $\left.\left(\frac{28}{100} \times 0,940285959\right)+\left(\frac{3}{100} \times 0\right)\right)=0,328351786$

3. Motivasi Siswa

Entropy $[$ Sangat Baik] =

Entropy [Baik]

Entropy [Cukup]

Entropy [Kurang]

Gain [Motivasi siswa]

$$
\begin{aligned}
& =0 \\
& =\left(-\frac{44}{51} \times \log _{2}\left(\frac{44}{51}\right)\right)+\left(-\frac{7}{51} \times \log _{2}\left(\frac{7}{51}\right)\right)=0,57700425 \\
& =\left(-\frac{3}{21} \times \log _{2}\left(\frac{3}{21}\right)\right)+\left(-\frac{18}{21} \times \log _{2}\left(\frac{18}{21}\right)\right)=0,591672779 \\
& =0 \\
& =0,811278124-\left(\left(\frac{28}{100} \times 0\right)+\left(\frac{51}{100} \times 0,57700425\right)+\left(\frac{21}{100} \times 0,591672779\right)+\right. \\
& \left.\left(\frac{0}{100} \times 0\right)\right)=0,392754673
\end{aligned}
$$

4. Cara Mengajar Guru

Entropy [Sangat Baik]

$$
\begin{aligned}
& =\left(-\frac{53}{56} \times \log _{2}\left(\frac{53}{56}\right)\right)+\left(-\frac{3}{56} \times \log _{2}\left(\frac{3}{56}\right)\right)=0,301378644 \\
& =\left(-\frac{21}{40} \times \log _{2}\left(\frac{21}{40}\right)\right)+\left(-\frac{19}{40} \times \log _{2}\left(\frac{19}{40}\right)\right)=0,998195879 \\
& =\left(-\frac{1}{4} \times \log _{2}\left(\frac{1}{4}\right)\right)+\left(-\frac{3}{4} \times \log _{2}\left(\frac{3}{4}\right)\right)=0,811278124 \\
& =0
\end{aligned}
$$

Entropy [Kurang]

Gain [Cara mengajar guru]

$$
\begin{aligned}
& =0,811278124-\left(\left(\frac{56}{100} \times 0,301378644\right)+\left(\frac{40}{100} \times 0,998195879\right)+\right. \\
& \left.\left(\frac{4}{100} \times 0,811278124\right)+\left(\frac{0}{100} \times 0\right)\right)=0,210776607
\end{aligned}
$$

5. Media Pembelajaran

$$
\begin{aligned}
& \text { Entropy [Sangat Baik] }=0 \\
& \text { Entropy [Baik] } \\
& =\left(-\frac{38}{48} \times \log _{2}\left(\frac{38}{48}\right)\right)+\left(-\frac{10}{48} \times \log _{2}\left(\frac{10}{48}\right)\right)=0,738284866 \\
& \text { Entropy [Cukup] } \\
& \text { Entropy [Kurang] } \\
& =\left(-\frac{5}{16} \times \log _{2}\left(\frac{5}{11}\right)\right)+\left(-\frac{11}{16} \times \log _{2}\left(\frac{11}{16}\right)\right)=0,896038233 \\
& =0 \\
& \text { Gain }\left[\text { Media pembelajaran] }=0,811278124-\left(\begin{array}{c}
\left(\frac{32}{100} x 0\right)+\left(\frac{48}{100} \times 0,738284866\right)+ \\
\left(\frac{16}{100} x 0,896038233\right)+\left(\frac{4}{100} x 0\right)
\end{array}\right)=0,313535272\right.
\end{aligned}
$$

6. Sarana Prasarana

$$
\begin{array}{ll}
\text { Entropy [Sangat Baik] } & =\left(-\frac{38}{39} \times \log _{2}\left(\frac{38}{39}\right)\right)+\left(-\frac{1}{38} \times \log _{2}\left(\frac{1}{38}\right)\right)=0,172036949 \\
\text { Entropy [Baik] } & =\left(-\frac{34}{40} \times \log _{2}\left(\frac{34}{40}\right)\right)+\left(-\frac{6}{40} \times \log _{2}\left(\frac{6}{40}\right)\right)=0,609840305 \\
\text { Entropy [Cukup] } & =\left(-\frac{3}{20} \times \log _{2}\left(\frac{3}{20}\right)\right)+\left(-\frac{17}{20} \times \log _{2}\left(\frac{17}{20}\right)\right)=0,609840305 \\
\text { Entropy [Kurang] } & =0
\end{array}
$$

Gain $[$ Sarana Prasarana $]=0,811278124-\left(\left(\frac{39}{100} x 0,172036949\right)+\left(\frac{40}{100} x 0,609840305\right)+\right.$

$$
\left.\left(\frac{20}{100} \times 0,609840305\right)+\left(\frac{1}{100} \times 0\right)\right)=0,378279531
$$

c. Dari hasil perhitungan pada tabel 1 diperoleh nilai atribut tertinggi adalah Motivasi Siswa dengan gain sebesar 0,392754673.Maka atribut Motivasi Siswa dipilih sebagai node akar.Ada empat kelas atribut dari Motivasi Siswa yaitusangat baik, baik, cukup dan kurang.Untuk kelas atribut sangat baik mengklasifikasikan kasus menjadi satu keputusan yaitu paham.Kelas atribut kurang adalah kosong, sehingga tidak perlu dilakukan perhitungan pada kelas atribut tersebut, nilai kelas atribut baik dan cukup belum diperoleh hasil antara keputusan paham dan tidak paham, maka perlu dilakukan perhitungan kembali untuk setiap cabang sampai semua kasus pada semua cabang memiliki kelas yang sama.

d. Proses perhitungan nilai entropy dan gain berhenti pada kelas cabang node 1.2.2 dengan node cabang atribut Motivasi Siswa $=$ Cukup dan Sarana dan Prasaran $=$ Baik adalah Minat Siswa. 
JURNAL MEDIA INFORMATIKA BUDIDARMA

Volume 5, Nomor 1, Januari 2021, Page 9-17

ISSN 2614-5278 (media cetak), ISSN 2548-8368 (media online)

Available Online at https://ejurnal.stmik-budidarma.ac.id/index.php/mib DOI 10.30865/mib.v5i1.2498

Dari hasil perhitungan tersebut diketahui semua kasus sudah masuk kedalam kelas yang sama. Berikut ini dapat digambarkan hasil pohon keputusan sebagai berikut :

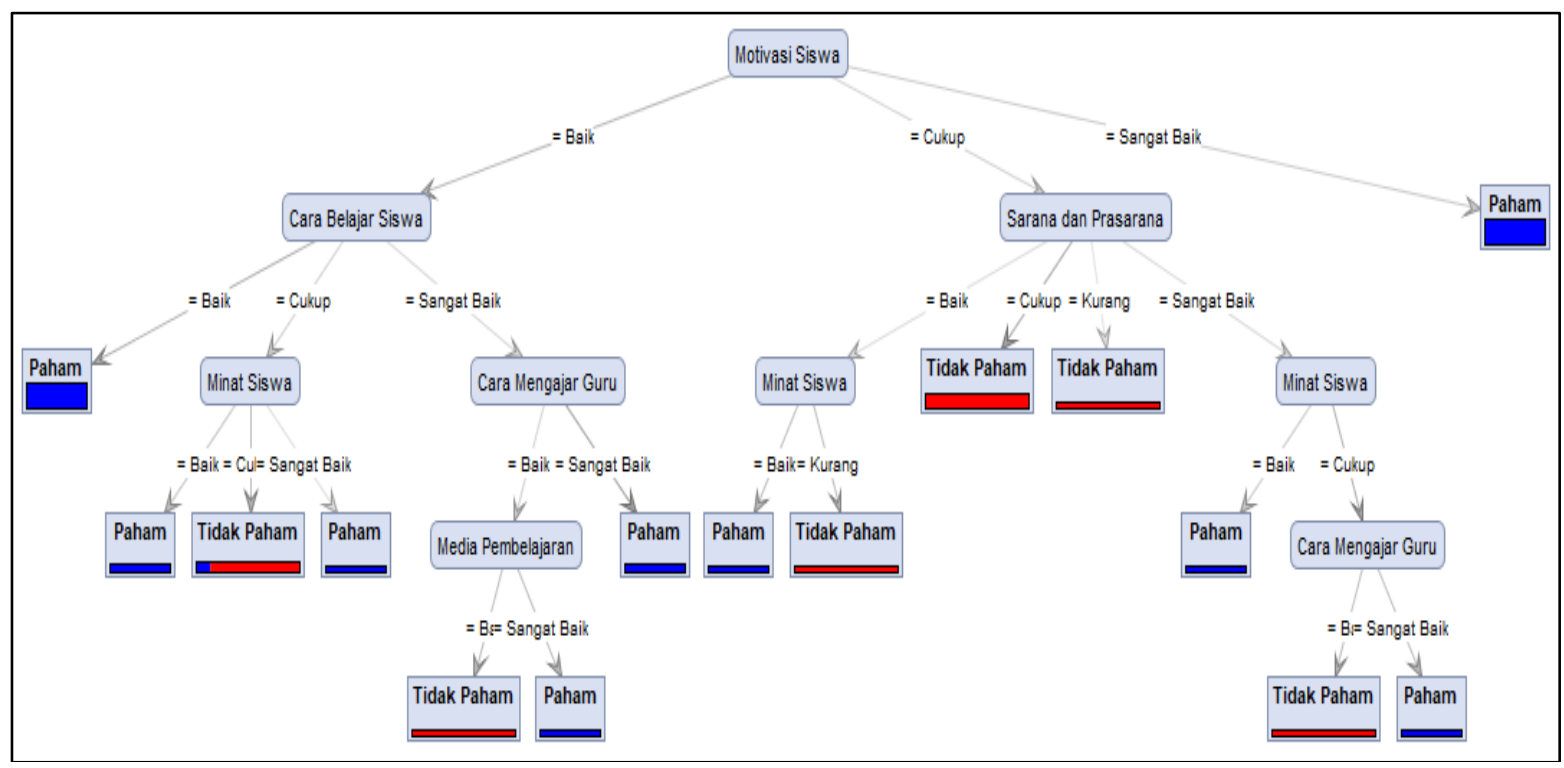

Gambar 3. Pohon Keputusan

Berdasarkan gambar diatas pada pohon keputusan diperoleh aturan atau rules keputusan sebagai berikut :

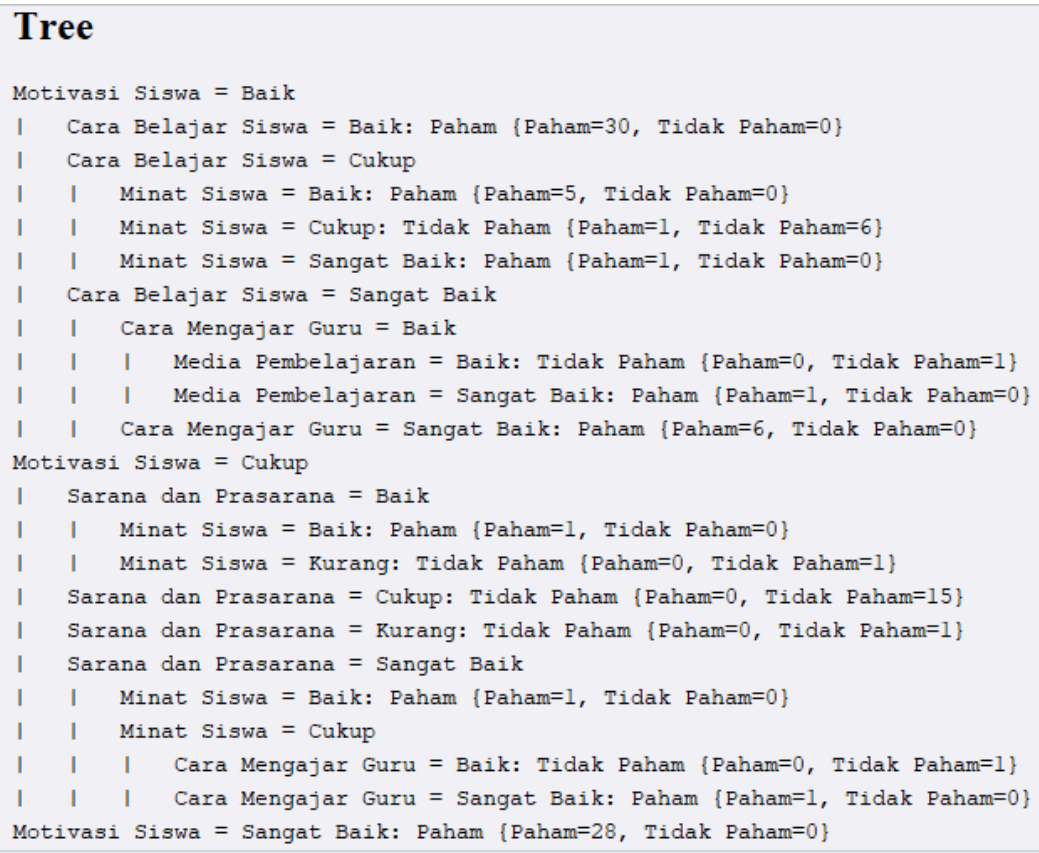

Gambar 4. Hasil Rules Pohon Keputusan

\subsection{Pengujian Klasifikasi dengan Software RapidMiner}

Dalam melakukan proses pengujian penulis menggunakan operator split validation yang digunakan untuk membagi data training dan testing. Pada area training menggunakan operator decision tree dan area testing menggunakan operator apply model dan performance classification. Berikut ini adalah hasil akurasi dari model klasifikasi yang dilakukan:

\begin{tabular}{|c|c|c|c|}
\hline & true Paham & true Tidak Paham & class precision \\
\hline pred. Paham & 47 & 1 & $97.92 \%$ \\
\hline pred. Tidak Paham & 1 & 1 & $50.00 \%$ \\
\hline class recall & $97.92 \%$ & $50.00 \%$ & \\
\hline
\end{tabular}

Gambar 5. Nilai Akurasi Algoritma C4.5 
Dari gambar di atas dapat dijelaskan hasil penerapan Algoritma C4.5 menggunakan software RapidMiner dengan operator Split Validationnilai akurasi sebesar 96,00\%, dimana hasil dari class precision label Paham sebesar 97,92\% dan label Tidak Paham sebesar 50\%. Parameter yang digunakan pada decision tree telah dilakukan penyesuaian terhadap kriteria decision tree yang digunakan pada RapidMiner yaitu information gain, maksimal depth $=20$, confidance $=0,25$, minimal gain $=0,1$, minimal leaf size $=1$, minimal size for split $=2$, numberof pruning alt $=3$.Dengan hasil performance vector Algoritma C4.5 sebagai berikut :

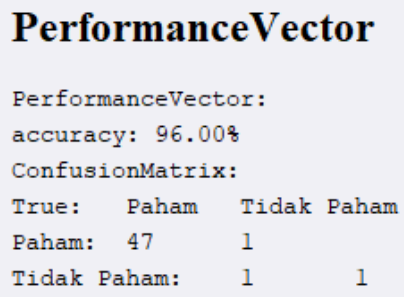

Gambar 6. Hasil Performa Model Algoritma C4.5

\section{KESIMPULAN}

Berdasarkan hasil penelitian dapat disimpulkan bahwa klasifikasi dengan Algoritma C4.5 dapat diterapkan pada kasus pemahaman pelajaran matematika siswa kelas VIII (delapan) SMP Swasta Tamansiswa Tapian Dolok yang diperoleh dari hasil perhitungan nilai entropy dan gain pada setiap atribut penilaian. Hasil penerapan Algoritma C4.5 telah didapatkan pohon keputusan dan rules yang menunjukkan bahwa atribut Motivasi Siswa sebagai faktor yang paling berpengaruh dalam keputusan pemahaman siswa pada pelajaran matematika, kemudian diikuti dengan atribut Cara Belajar Siswa, Sarana dan Prasarana, Minat Siswa, Cara Mengajar Guru dan Media Pembelajaran. Hasil penerapan Algoritma C4.5 dapat diuji dengan Software Rapidminer dan diperoleh yang sama dengan perhitungan manual dengan pemodelan Algoritma C4.5 menghasilkan akurasi sebesar 96,00\%. Hasil penelitian dapat menjadi perhatian khusus bagi pihak sekolah untuk mendukung dan membantu siswa agar dapat memahami pelajaran matematika sehingga siswa mampu untuk meningkatkan prestasi siswa pada bidang akademik khususnya matematika.

\section{UCAPAN TERIMAKASIH}

Terima kasih kepada SMP Swasta Tamansiswa Tapian Dolok yang telah memberikan dukungan dan izin penelitian serta Bapak Ibu Dosen AMIK dan STIKOM Tunas Bangsa Pematangsiantar yang telah membimbing penulis dalam menyelesaikan penelitian ini.

\section{REFERENCES}

[1] S. M. Khasanah, "Pengaruh Pemahaman Konsep dan Motivasi Belajar Terhadap Hasil Belajar Materi Trigonometri Siswa Kelas X MIA 2 di MAN 3 Tulungagung,” INSTITUT AGAMA ISLAM NEGERI TULUNGAGUNG, 2018.

[2] P. P. P. A. N. . F. I. R. . Zer, D. Hartama, and S. R. Andani, "Analisa Faktor Dominan Mahasiswa Kesulitan Memahami Bahasa Pemrograman," in Prosiding Seminar Nasional Riset Information Science (SENARIS), 2019, no. September, pp. 492-500.

[3] R. T. Vulandari, Data Mining Teori dan Aplikasi Rapidminer, 1st ed. Yogyakarta: Peberbit Gaya Media, 2017.

[4] S. Hawani, D. Hartama, A. P. Windarto, and Solikun, "PENERAPAN C 4.5 UNTUK MENENTUKAN CALON SUAMI TERBAIK DALAM PERNIKAHAN PADA KANTOR KUA SIANTAR MARTOBA PEMATANGSIANTAR," vol. 1, pp. 64-68, 2016.

[5] N. Rofiqo, A. P. Windarto, and E. Irawan, "Penerapan Algoritma C4 . 5 pada Penentuan Tingkat Pemahaman Mahasiswa Terhadap Matakuliah," in Prosiding Seminar Nasional Riset Information Science (SENARIS), 2019, no. September, pp. 307-317.

[6] D. R. Sitorus, A. P. Windarto, D. Hartama, and I. S. Damanik, "PENERAPAN KLASIFIKASI C4.5 DALAM MENINGKATKAN SISTEM PEMBELAJARAN MAHASISWA," KOMIK (Konferensi Nas. Teknol. Inf. dan Komputer), vol. 3, no. 1, pp. 593-597, 2019.

[7] A. P. Windarto, U. Indriani, M. R. Raharjo, and L. S. Dewi, "Bagian 1: Kombinasi Metode Klastering dan Klasifikasi (Kasus Pandemi Covid-19 di Indonesia),” J. Media Inform. Budidarma, vol. 4, no. 3, p. 855, 2020.

[8] S. H. Waluyo and Prihandoko, "Klasifikasi Pemanfaat Program Beras Sejahtera ( RASTRA ) Berdasarkan Tingkat Kemiskinan Dengan Menggunakan Algoritma Decision Tree C4 . 5 Berbasis Particle Swarm Optimization,” vol. 7, no. 2, pp. 19-24, 2017.

[9] D. I. G. Hts, "Penerapan Algoritma C4.5 Untuk Penerimaan Siswa Baru Pada SMA Al-Azhar Medan," J. Sains Komput. Inform., vol. 2, no. 2, pp. 130-139, 2018.

[10] I. S. Damanik, A. P. Windarto, A. Wanto, Poningsih, S. R. Andani, and W. Saputra, "Decision Tree Optimization in C4.5 Algorithm Using Genetic Algorithm," in Journal of Physics: Conference Series, 2019, vol. 1255, no. 1.

[11] N. Khotimah and D. Istiawan, "Perbandingan Algoritma C4.5, Naïve Bayes dan K-Nearest Neighbour untuk Prediksi 
JURNAL MEDIA INFORMATIKA BUDIDARMA

Volume 5, Nomor 1, Januari 2021, Page 9-17

ISSN 2614-5278 (media cetak), ISSN 2548-8368 (media online)

Available Online at https://ejurnal.stmik-budidarma.ac.id/index.php/mib

DOI 10.30865/mib.v5i1.2498

Lahan Kritis di Kabupaten Pemalang," Urecol, vol. 7, no. 1, pp. 41-50, 2018.

[12] Taufiq and Y. Yudihartanti, "Penerapan Algoritma C4.5 Klasifikasi Tingkat Kelulusan Mahasiswa," in Seminar Nasional Ilmu Komputer (SOLITER), 2019, vol. 2, pp. 153-162.

[13] A. Rohman, V. Suhartono, and C. Supriyanto, "Penerapan Agoritma C4.5 Berbasis Adaboost Untuk Prediksi Penyakit Jantung," J. Teknol. Inf., vol. 13, pp. 13-19, 2017.

[14] D. Nofriansyah and G. W. Nurcahyo, Algoritma Data Mining Dan Pengujian. Deepublish, 2019.

[15] N. Yahya and A. Jananto, "Komparasi Kinerja Algoritma C.45 dan Naive Bayes UNTUK Prediksi Kegiatan Penerimaan Mahasiswa Baru (Studi Kasus : Universitas STIKUBANK Semarang),” in SENDI_U, 2019, pp. 221-228.

[16] H. M. Nawawi, S. Rahayu, M. J. Shidiq, and J. J. Purnama, "Algoritma C4.5 untuk Memprediksi Pengambilan Keputusan Memilih Deposito Berjangka,” J. Techno Nuasa Mandiri, vol. 16, no. 1, pp. 65-72, 2019.

[17] A. H. Nasrullah, "Penerapan Metode C4.5 Untuk Klasifikasi Mahasiswa Berpotensi Drop Out," Ilk. J. Ilm., vol. 10, no. 2, pp. 244-250, 2018.

[18] N. Anwar, A. Pranolo, and R. Kurnaiwan, "Grouping the community health center patients based on the disease characteristics using C4.5 decision tree," in IOP Conference Series: Materials Science and Engineering, 2018. 